\title{
The varieties of capitalism paradigm: not enough variety?
}

\section{Matthew Allen}

Institute for German Studies, European Research Institute, Birmingham University, Birmingham B15 2TT, UK

Correspondence: m.m.allen@bham.co.uk

This paper attempts to shed light on some of the unstated assumptions of the varieties of capitalism framework by comparing it with its 'close relative' that is, transaction cost economics-as well as neoclassical economics. These comparisons show that, within the varieties of capitalism approach, actors' strategic preferences are assumed to be endogenous to the institutional environment in which they operate. Moreover, important institutions are assumed to be uniformly spread across firms within a national economy. This latter presupposition ultimately makes the varieties of capitalism framework a structuralist approach. Despite its claims to the contrary that it is an actor-centred approach, the varieties of firms paradigm treats the varieties of firms as irrelevant. It is this variety that is lacking in the approach, and that needs to be addressed in any empirical assessments of it.

Keywords: varieties of capitalism, transaction cost economics, institutions: collective agreements, works councils, Germany

JEL classification: B25 institutional economic thought, B13 neoclassical economic thought, D23 organizational behaviour; transaction costs; property rights

\section{Introduction}

This paper ${ }^{1}$ will, by attempting to clarify some of the (oft-unstated) assumptions that underlie the varieties of capitalism approach as well as those that underpin

\footnotetext{
${ }^{1}$ I would like to thank the Fritz Thyssen Foundation for their financial support, which enabled me to write this article. My thanks are also owed to two anonymous reviewers for their very helpful comments on a previous version of this article.
} 
neoclassical and transaction $\operatorname{cost}^{2}$ economics, ${ }^{3}$ call for greater methodological clarity in linking institutions to outcomes. Despite the fact that the varieties of capitalism perspective draws explicitly on some of the contentions advanced within the transaction cost literature-particularly those concerned with the generation of firm-specific skills - the two perspectives offer diametrically opposed views on the benefits of state-supported ${ }^{4}$ institutions such as works councils and collective agreements: writers within the varieties of capitalism paradigm contend that there are benefits; transaction cost economists that there are none, and that there are, indeed, costs. This point has hitherto been overlooked.

This article will seek to argue that this difference of opinion ultimately rests on an assumption made about the origins of those institutions that can be beneficial to companies: within the varieties of capitalism approach, state-supported institutions, such as, in the German case, ${ }^{5}$ works councils and collective agreements, can offer benefits to companies. This stands in stark contrast to the assumption within the other two approaches examined here-neoclassical and transaction cost economics — both of which assume that firms themselves will be able to set up any firm-level institutions that they may need to facilitate their strategies. ${ }^{6}$ From this

\footnotetext{
${ }^{2}$ Put simply, transaction costs arise whenever economic actors engage in, or seek to engage in, trade. These costs potentially include search costs (the costs associated with trying to find an economic partner or trying to ascertain which potential partner offers the best price, quality or value), bargaining costs (the costs of negotiating a deal), monitoring costs (the cost of ensuring that contracts are being adhered to), enforcement costs (the price that must be paid for the enforcement of a contract, which can include legal costs), and the cost of maintaining the system as a whole (courts, the police, etc.). Transaction cost economics seeks to assess the way in which these costs influence the actions of economic agents.
}

${ }^{3}$ There are, of course, analyses of capitalism that rest on a sociological institutionalist framework; these will not, however, be examined here. Important books within this framework, although there are differences between them, are: Hollingsworth and Boyer (1999); Herrigel (2000); Whitley (2000).

${ }^{4}$ The term 'state-supported institutions' will-even if a little cumbrous-be used in preference to the
word 'mandatory' as firms do not have to have a works councils and adhere to (the minimum terms and
conditions of) a sectoral collective agreement (although industry-wide collective agreements are often
used as the basis for firm- or plant-level collective agreements). For the former, workers must vote to
establish one; for the latter, firms must be members of the relevant employers' association. It should also
be noted that firms, if they so wish, can exceed the pay and conditions set out in sectoral collective
agreements.

${ }^{5}$ Many of the arguments that relate to 'co-ordinated market economies' (CMEs) in this paper will make reference to Germany. It is, of course, true that, within Hall and Soskice's (2001) typology, more countries are classified as CMEs; however, Germany can, perhaps, be considered as the CME paragon. Hopefully, therefore, the lack of references to other CMEs is justified.

${ }^{6}$ To be sure, neoclassical and transaction cost economists would not deny that the state has a crucial role to play in establishing institutions such as the rule of law (protection of property rights) and 
assumption within the varieties of capitalism literature at least two others follow. First, the varieties of capitalism approach assumes that national institutions — such as works councils and collective agreements-are uniformly present across sectors and firms. Secondly, within the varieties of capitalism paradigm, it is implicitly argued that institutions can shape preferences; by contrast, within transaction cost and neoclassical economics, preferences are exogenous to the institutional setting. Whilst the main focus of this paper will be on comparing the different approaches, the paper will include with a few observations on how some of these unstated assumptions within the varieties of capitalism paradigm have inadequately been taken into account in some of the studies that have examined the empirical implications of the approach. For instance, some of the empirical assessments of the arguments espoused within the varieties of capitalism framework have failed to take the uneven spread of institutions in Germany into consideration. Therefore, greater care should be taken in designing research to account for this heterogeneity.

This article proceeds as follows. First, the main contention of the varieties of capitalism paradigm will be outlined. The interrelated assumptions that underpin the three approaches examined here on actor rationality and the 'completeness' of information available to actors will then be discussed. This will be followed by an overview of the different views on actor opportunism taken in the varieties of capitalism paradigm and transaction cost economics, on the one hand, and in neoclassical economics, ${ }^{7}$ on the other. The implications of the different positions taken on actor opportunism for assumptions made about the nature of the firm will then be discussed. The way in which institutions can theoretically act as constraints on actors to reduce opportunism and strategic uncertainty, and, hence, change the strategic interaction of actors will then be examined. The assumptions pertaining to institutions as constraints raise obvious issues of power. The different ways in which power is conceived in the approaches examined here will be then be adumbrated, as will the strategic preferences of actors, and the origins of institutions. (Table 1 offers a summary of some of the stylized differences and similarities between the three approaches.) The methodological implications of some of these assumptions for the varieties of capitalism paradigm will then be sketched out. Finally, conclusions will be drawn.

national defence that are prerequisites for many businesses to function; both schools of thought would contend, however, that above and beyond these institutions, the company should be free to decide which additional institutions it needs.

\footnotetext{
${ }^{7}$ It should be noted at the outset that the image presented here of neoclassical economics is of the 'unvarnished' or 'highly' neoclassical kind. It is, thus, an ideal type. A more realistic protrayal of current neoclassical economics would, for example, have to take into consideration the fact that many who consider themselves neoclassical economists now employ the new economics of organization, and various kinds of game theory allow for incomplete information and strategic interaction.
} 
Table 1 Stylized portrayal of different approaches: key differences and similarities

\begin{tabular}{|c|c|c|c|}
\hline & Varieties of capitalism & Transaction-cost economics & Neoclassical theory \\
\hline Origins of institutions & Unclear & Actors & Actors \\
\hline Agency or structure & Structure. Strategy follows structure & Actor. Structure follows strategy & $\begin{array}{l}\text { Actor. Structure follows } \\
\text { strategy }\end{array}$ \\
\hline $\begin{array}{l}\text { Rationality and } \\
\text { opportunism }\end{array}$ & $\begin{array}{l}\text { Actors exhibit bounded rationality } \\
\text { Actors are opportunistic }\end{array}$ & $\begin{array}{l}\text { Actors exhibit bounded rationality } \\
\text { Actors are opportunistic }\end{array}$ & $\begin{array}{l}\text { Homo economicus-actors are } \\
\text { 'completely' rational } \\
\text { Actors are self-interested }\end{array}$ \\
\hline Role of institutions & $\begin{array}{l}\text { Reduce uncertainty and opportunism by } \\
\text { acting as credible commitments }\end{array}$ & $\begin{array}{l}\text { Can reduce uncertainty and opportunism; } \\
\text { however, also confer power on actors }\end{array}$ & $\begin{array}{l}\text { Confer power unjustifiably on } \\
\text { actors. Institutions seen } \\
\text { as a system of incentives and } \\
\text { disincentives }\end{array}$ \\
\hline View of power & Power reduces opportunism & $\begin{array}{l}\text { Power can be used to reduce opportunism } \\
\text { Power can be exploited by those with } \\
\text { general skills }\end{array}$ & $\begin{array}{l}\text { Power can be exploited by } \\
\text { those who should not have it }\end{array}$ \\
\hline $\begin{array}{l}\text { Why do institutions } \\
\text { persist? }\end{array}$ & They offer benefits to companies & Political compromises & Political compromises \\
\hline $\begin{array}{l}\text { Actors' pre-strategic } \\
\text { preferences }\end{array}$ & Not important & Determined by firm's production strategy & $\begin{array}{l}\text { Firms want minimum of } \\
\text { government interference }\end{array}$ \\
\hline $\begin{array}{l}\text { Actors' strategic } \\
\text { preferences }\end{array}$ & Endogenous to institutional framework & Same as pre-strategic preferences & $\begin{array}{l}\text { Same as pre-strategic } \\
\text { preferences }\end{array}$ \\
\hline $\begin{array}{l}\text { Corollary of above for } \\
\text { investment decisions }\end{array}$ & Production is not completely 'footloose' & $\begin{array}{l}\text { Production seen as 'footloose', as firms can set } \\
\text { up the institutions they need }\end{array}$ & $\begin{array}{l}\text { Production seen as 'footloose'; } \\
\text { firms will move to those } \\
\text { countries with institutions } \\
\text { that interfere with market } \\
\text { mechanisms the least, ceteris } \\
\text { paribus }\end{array}$ \\
\hline $\begin{array}{l}\text { Economic benefits to state- } \\
\text { supported institutions? }\end{array}$ & Yes & $\begin{array}{l}\text { No (though state needed to secure property } \\
\text { rights etc.) }\end{array}$ & $\begin{array}{l}\text { No (though state needed to } \\
\text { secure property rights etc.) }\end{array}$ \\
\hline
\end{tabular}


The varieties of capitalism framework has recently drawn a great deal of attention within the literature on political economy. In many respects, it can be seen as a historical institutionalist approach to the study of capitalism. Though the transaction costs approach to the study of capitalism does not fit into the institutionalist framework very easily, it is closely related to the varieties of capitalism approach, especially in its assumptions on actor rationality, actor opportunism and the importance of asset specificity to analyses of companies. The other school of thought examined here- the neoclassical approach—can be thought of as belonging more to the rational choice framework.

In short, the varieties of capitalism approach to the study of capitalism rests on the argument that different national economic institutions-which can include such things as the financial system, the vocational training system and the industrial relations system —offer different opportunities to companies; as companies are likely to be aware of these opportunities, firms will, on the whole, adjust their production strategies as well as their use of different types of human capital (either general or firm specific) to take advantage of these opportunities. As these institutions, and, hence, opportunities, differ between countries — or at least between groups of countries [Hall and Soskice (2001) distinguish between 'coordinated market economies', or CMEs such as Germany and Sweden, and 'liberal market economies', or LMEs such as the USA and the UK] - firms within these groups of nations are likely to excel at producing different goods; this is likely to be reflected in the comparative advantage for that group of countries. Therefore, the varieties of capitalism approach contends that a nation's economic institutions lay the foundations for its comparative advantage.

As will be shown, the arguments in the varieties of capitalism literature have a great deal in common with those made by transaction cost economists; there are, however, important differences between these two schools of thought on the role that institutions can play in shaping the strategic preferences of actors as well as on the origins of institutions. Before discussing those main differences, this paper will examine some of the broader similarities between the two approaches as well as some of their differences to the neoclassical paradigm.

\section{Actor rationality and the 'completeness' of information}

The degree to which actors can be thought of as rational is one of the main ontological assumptions within any theory. ${ }^{8}$ It is also one that is directly related to assumptions on the amount of information available to actors. One difficulty in assessing the

\footnotetext{
${ }^{8}$ See Thelen and Steinmo (1992, pp. 7-10) for a description of the differences between historical institutionalists and rational choice institutionalists; see Williamson (1985, pp. 44-7) on boundedas well as other forms of-rationality; see North (1992, pp. 17-26), for a broader discussion of behavioural assumptions.
} 
assumptions about actor rationality and the 'completeness' of information within the varieties of capitalism paradigm is that they are not discussed explicitly. Notwithstanding such difficulties, it is clear from analyses of writers who adhere to the varieties of capitalism framework that, like transaction cost economists, they tend to assume that, $a b$ initio, actors have bounded rationality. This assumption stems, in part, from an assumption within the varieties of capitalism framework that information is not 'costlessly' available.

Unsurprisingly, the assumption that information is not freely available lies at the heart of transaction cost economics. Some writers within transaction cost economics have argued that, because transaction costs will always hinder the spread of information, it cannot, ipso facto, be assumed that actors will ever have perfect information (Furubotn and Richter, 1998, pp. 453-82). Moreover, the fact that actors have incomplete information means that they cannot be completely rational. Therefore, the assumption made about actor rationality is closely tied to that on the importance of transaction costs.

Within the transaction costs approach, Williamson has distinguished between three forms of rationality: maximizing rationality, bounded rationality and organic rationality (Williamson, 1985, pp. 44-7). The first of these can be thought of as lying at the heart of the neoclassical approach which often makes the attendant assumption-discussed below-that all decision makers have complete information. The varieties of capitalism and the transaction costs approaches tend to assume that economic actors are 'intendedly rational, but only limited so' (Simon, 1961 [1947], xxiv). Yet such a definition of bounded rationality raises the question of what actors are 'limited' by. Scott (1994, p. 315) has observed that bounded rationality can be categorized into three types: rationality bounded by an inability to access pertinent, but existing information; by the lack of complete information; and by the cognitive inability of actors to make the correct decision based on complete information that is readily available to them.

The type of rationality that underpins the varieties of capitalism paradigm is bounded rationality. Even if the varieties of capitalism approach is interpreted in such a way that its views on institutions as means by which to facilitate the exchange of information so that a situation of maximizing rationality can be assumed are given prominence (as is done by Culpepper, 2003, pp. 11,16,21), the type of bounded rationality that, $a b$ initio, underpins the varieties of capitalism approach is that which is bounded by the inability to access pertinent information that does exist. Such an interpretation certainly has its merits as Hall and Soskice also integrate some aspects of game theory into their approach. Although this might suggest that they adopt an assumption of maximizing rationality (2001, p. 5), it should not be overlooked that many of their arguments are concerned with the way in which certain institutions can help to reduce other transaction costs (either by facilitating the exchange of information or by easing problems associated with monitoring and 
sanctioning) (2001, pp. 10-11). In short, within the varieties of capitalism paradigm, actors are, initially, limited in the amount of information that they have available to them; they are not, however, limited by their cognitive abilities to process that information 'correctly' once they have it. ${ }^{9}$

These views, in some ways at least, are at odds with the views on actor rationality and the completeness of information in transaction cost economics. For instance, whilst transaction cost economists and others have noted that institutions can help to reduce the transaction costs associated with the process of acquiring information (Stiglitz, 1985, p. 36; North, 1994, p. 4; Furubotn and Richter, 1998, p. 465), some would appear to be reluctant to advocate a view of the world in which institutions can help to reduce the 'incompleteness' of information to such an extent that the assumption of perfect information is, for practical purposes, valid (Furubotn and Richter, 1998, pp. 464, 468). In short, many transaction cost economists would argue that, as transaction costs will never disappear entirely, actors will only ever have incomplete information, and will, therefore, be rational in a bounded way only; if it is argued that transaction costs prevent the spread of information, it cannot, ipso facto, be assumed that actors have perfect information, and it cannot, therefore, be assumed that actors make decisions that are consistent with the assumptions of maximizing rationality (Furubotn and Richter, 1998, pp. 453-82).

Yet, despite these differences, both approaches base their analyses on the twin premises of bounded rationality and non-zero transaction costs. This stands in sharp contrast to the neoclassical approach, which often makes assumptions of perfect information (Kasper and Streit, 1998, p. 52), and which presupposes that information can be obtained freely. In the 'standard neoclassical Walrasian model', exchange is instantaneous, individuals are fully informed about the commodity to be exchanged and the terms of trade are known to those involved in the exchange (North, 1990, p. 30). On the basis of this perfect information, it becomes possible to assume that actors can behave in a completely rational way: if they have all the relevant information, and have the correct cognitive framework upon which to base their decisions, they must be able to act in a completely rational manner.

\section{Actor opportunism}

Whilst some interpretations of the varieties of capitalism framework might focus on the role of institutions as facilitators of information exchange, an alternative, but equally valid, understanding of the varieties of capitalism paradigm might be to place more emphasis on its arguments on institutions as credible commitments;

\footnotetext{
${ }^{9}$ Cf. Hollingsworth et al. (2002) where they present the view of sociological institutionalism that institutions, inter alia, provide cognitive frameworks for dealing with complex situations.
} 
that is, institutions as constraints. Though only the assumptions made about actor opportunism will be discussed in this section, the premises made on actor opportunism and institutions as constraints are, like those on rationality and the completeness of information, closely linked. Similarly, the assumptions that underpin the varieties of capitalism paradigm and those that underlie transaction cost economics distinguish them from neoclassical economics. Both the varieties of capitalism framework and transaction cost economics place the issue of actor opportunism at the heart of their analyses.

Williamson (1985, pp. 47-50, 64-7) has defined opportunism as 'self-interest seeking with guile', and distinguishes it from 'simple self-interest seeking' and obedience. He argues that, if actors are assumed to be opportunistic, they cannot be relied upon to reveal all relevant information at all times. If actors are assumed to reveal such information at all times, they behave in a simple self-interest-seeking manner. This distinction may seem a somewhat nebulous one, but Williamson (1985, pp. 65-6) has sought to defend himself against claims that there is no real difference between simple self-interest seeking and opportunism by asking if an appreciation of opportunism [had been] widespread, what explains the dramatic impact of George Akerlof's treatment of the "lemons problem" in 1970?' (Akerlof examined the effects on the used-car market of sellers withholding information about the quality of their cars.)

Within the varieties of capitalism framework, no explicit reference is made to actor opportunism. Again, however, it is clear that the framework shares the assumption of actor opportunism with transaction cost economics. For instance, like transaction cost economics, the varieties of capitalism framework deals with potential problems of post-agreement implementation. Thus, in both approaches, it is assumed that contracts will be an insufficient means to prevent opportunistic behaviour. Therefore, because contracts will always be incomplete, there will be possibilities for actors to behave opportunistically. This applies a fortiori if it is also assumed that transaction costs must be incurred both to monitor and to enforce agreements.

To be sure, some of the expost problems of implementation, such as adverse selection, moral hazard, and principal-agent problems, have become a part of neoclassical analyses (Williamson, 2000, p. 596); yet, such analyses can often be criticized for mixing contradictory assumptions. All these problems deal with asymmetric information, and, therefore, deal with transaction costs and bounded rationality. As noted earlier, it would appear to be impossible to combine elements of neoclassical economics with parts of transaction cost economics as this leads to contradictory assumptions being made about actor rationality (but cf. North, 1990). Moreover, it can lead to contradictory assumptions being made about the amount of information available to actors and actor opportunism. For instance, if actors are assumed to be fully informed, it is impossible for actors to engage in opportunistic behaviour, as other actors will be aware of this. Moreover, even if, within neoclassical economics, 
actors are assumed to be opportunistic, neoclassical economists tend to argue that it can be prevented by (complete) contracts, as - if it is assumed that the actors are fully informed-all future contingencies can be incorporated into the terms of a contract.

\section{The nature of the firm}

The assumption of actor opportunism by transaction cost economists as well as by those who favour the varieties of capitalism approach has important ramifications for their arguments. In particular, both schools of thought contend that institutions can help to overcome the problem of opportunism. As neoclassical economists do not attach as much significance to the problem of opportunism, it is not surprising that many of their analyses have different starting positions. Before examining more closely how institutions might overcome the problem of actor opportunism, it will be worth commenting briefly on these different starting positions.

Unlike neoclassical economists who view the firm as a production function or 'black box' (Arrow, 1999) and who focus their attention on how 'changes at the margin' in the provision of factors of production influence output, writers in the varieties of capitalism approach as well as transaction cost economists assume that factors of production cannot be taken as a given. They, therefore, seek to explain how certain goods and services are provided within economic relationships. Moreover, they assume, unlike many neoclassical economists, that contracts cannot be relied upon to guarantee completely how those factors of production will be used (Williamson, 1985; Milgrom and Roberts, 1992; Furubotn and Richter, 1998, pp. 46-7). In short, transaction cost economists as well as those who support the varieties of capitalism paradigm start from a relational view of the firm and focus on problems of co-ordination between different actors. Whilst this focus is relatively novel within political economy (Hall, 2001; Hall and Soskice, 2001, pp. 2-4), it is not an altogether new one for transaction cost economists. Both schools of thought argue that the types of co-ordination that are possible between actors are likely to depend, in part at least, on the actors' institutional environment.

In more specific terms, this view of the firm comes to focus on the relationships that firms have both with external organizations (suppliers, trade unions, business associations and government) and with 'domestic' actors (the company's employees). Hall and Soskice contend that it is the quality of these relationships and the manner in which firms overcome or govern co-ordination problems that are critical in determining company success. These co-ordination problems are, in turn, characterized by transaction costs. The concern of the varieties of capitalism literature and of transaction cost economists lies in analysing the effects that different institutional frameworks have, firstly, on reducing these transaction costs, and, secondly and consequently, on the type of co-ordination between actors, which is facilitated by different institutional settings (Hall and Soskice, 2001, p. 6). 
In particular, transaction cost economists as well as analysts using the varieties of capitalism framework have noted the problems surrounding the provision of goods or services that are asset specific; that is, assets — which can include firm-specific human capital — that would have, by definition, little value if they were offered on the open market. Thus, if a firm uses a machine that has been especially designed for it, the machine's operators and mechanics will become well versed in running and repairing the machine; however, the skills they garner will be of less value to other firms using different machines. Training workers to have firm-specific skills is likely to be especially difficult in an uncertain world that is assumed to be inhabited by opportunistic actors. Within the literature on transaction costs and within the literature on the varieties of capitalism, it is argued that the provision of firm-specific human capital (as well as goods and services) will require institutional settings that can overcome the problem of opportunism, most notably, the problem of 'hold up'.

\section{Institutions as constraints, and uncertainty}

It is the contention within both schools of thought that, unless an actor or a group of actors makes credible commitments not to exploit another actor or group of actors who have invested in firm-specific skills after they have reached an agreement, the investment in firm-specific skills is unlikely to happen. For instance, a firm might offer to train a worker with firm-specific skills and to pay that worker at a similar rate to workers with general skills; however, after the training has taken place, the firm might argue that, for financial reasons, the firm can only pay the worker at a lower rate. The firm might try to exploit the fact that the worker has few options as his/her skills are of little value to other firms. Similarly, workers with firm-specific skills might not be as diligent as workers with general skills because they cannot be replaced as easily, as it costs the firm time and money to train other people to do the job. Therefore, for both reasons the training is unlikely to take place unless both sides to the deal make a credible commitment to one another.

For transaction cost economists and for writers within the varieties of capitalism approach, these problems of potential exploitation can be overcome by the presence of appropriate institutions (Ostrom, 1990). Williamson (1985, p. 243, emphasis in the original) has noted that 'skills... that are imperfectly transferable across employers have to be embedded in a protective governance structure lest productive values be sacrificed if the employment relation is unwittingly severed. ${ }^{10}$ Hall and Soskice have been a little more specific in the type of institutions that they see as providing a protective governance structure for skills that are imperfectly transferable across employers; that is, for skills that are firm specific. They have

\footnotetext{
${ }^{10}$ Williamson (1985, pp. 302-3) has noted that in the absence of safeguards, such as co-determination, workers with firm-specific skills will demand higher wages.
} 
argued that works councils provide 'employees with security against arbitrary layoffs or changes to their working conditions', and they, thereby, 'encourage employees to invest in company-specific skills and extra effort' (2001, p. 25, see also p. 24).

Hall and Soskice also go on to argue that other institutions of CMEs help to reinforce workers' long-term commitments to their employers that result from workers investing in firm-specific skills. For instance, in Germany, the collective wage bargaining system, because it equalizes wages at 'equivalent skill levels across an industry' assures workers 'that they are receiving the highest feasible rates of pay in return for the deep commitments they are making to firms' (2001, p. 25). In Germany, the 'highest feasible rates' for workers are received as the result of the negotiations that initially take place between a powerful union (often the Metalworkers' Union) and the respective employers' association in one Land (often BadenWürttemberg in which the Metalworkers' Union is particularly powerful). The agreement reached is then used as a pilot agreement between other unions and employers' associations in other Länder. Thus, both works councils and powerful unions constrain employers in their ability to act opportunistically either by arbitrarily changing working conditions or by paying workers with few outside options low wages.

In short, within the varieties of capitalism framework, and within transaction cost economics, institutions can facilitate credible commitments between actors, reduce actor opportunism (see also Allen, 2002b; Kasper and Streit, 1998, p. 118), and, thereby, reduce strategic uncertainty ${ }^{11}$ amongst actors. As Hall and Soskice (2001, p. 10) have written:

In general these [institutions that offer higher returns to all concerned] will be institutions that reduce the uncertainty actors have about the behaviour of others and allow them to make credible commitments to each other.

Pejovich, who shares many of the assumptions of transaction cost economists, ${ }^{12}$ has expressed himself in a similar way. He has also noted $(1998$, p. 24) that, if institutions are to make the behaviour of actors more predictable, they must themselves be stable and enforceable.

A major function of the rules of the game is to reduce the transaction costs of human interactions through making human behaviour predictable. To accomplish this objective, institutions must be credible (i.e. enforced) and stable.

The concern to have an appropriate institutional framework to encourage firms and workers to invest in firm-specific skills stems, in part, then, from a view of actor

\footnotetext{
11 This can crudely be summed up as actors not knowing what other actors in the same 'game' will do.

${ }^{12}$ Pejovich would consider himself a property rights theorists. For a comparison of transaction cost economics with property rights theory, see Williamson (2000, pp. 605-10).
} 
opportunism and the availability of information that is shared by transaction cost economists and writers within the varieties of capitalism approach; these assumptions are not, however, as noted above, shared by neoclassical economists. It is not surprising that neoclassical economists, who have a slightly different view of human nature, do not call for institutions to overcome the problem of opportunism, and see no need for institutions to encourage certain types of strategic interaction between actors. North (1997, p. 2, see also Barzel, 1997, p. 11) has even gone so far as to say that 'neoclassical economic theory is devoid of institutions'.

\section{Institutions as sources of power}

To be sure, neoclassical economists do not ignore the effects of institutions on the behaviour of actors (IMF, 1999, p. 95; Siebert, 1997; Sinn, 2002); however, they tend to neglect the effects that institutions can have on the strategic interaction between actors - that is, those effects that are stressed by those who favour the varieties of capitalism framework. ${ }^{13}$ Instead, neoclassical economists tend to focus on the power aspects of institutions. It can, of course, be argued that the varieties of capitalism paradigm - as well as transaction cost economics in its contentions on firmspecific assets (Williamson, 1985, 1993; Eggertson, 1996, p. 15)—do not overlook the power aspects of institutions. For instance, arguments that are based on the concept of credible commitments make assumptions about power: institutions can act as checks and balances on actors to militate against actor opportunism, and, hence, facilitate outcomes that can be mutually beneficial. Within the varieties of capitalism paradigm, then, power is viewed positively; it is also assumed that actors are involved in a non-zero-sum game.

Within neoclassical economics - and within transaction cost economics when assessments of the effects of state-supported co-determination are made-however, the concept of power, within this context, is often presented in a more negative light. In some ways, the concept of power in neoclassical writings on labour-market institutions shares many affinities with that used by classical pluralists. Thus, power is seen, to paraphrase Dahl (1957, p. 201) as a means by which actors can make other actors do something they would not otherwise do in situations where there is a known conflict of interest. Moreover, power is seen as zero-sum: if one actor, or group of actors, gains, another actor, or group of actors, loses out. In addition, like classical pluralists, neoclassical economists tend to assume that the material interests of actors - which can be readily defined - are equal to the preferences of actors.

\footnotetext{
${ }^{13}$ The emphasis of transaction cost economists is - at least as far as state-supported co-determination is concerned-ultimately on the power aspects of institutions.
} 
Within neoclassical economics, the power actors have often derives, in part at least, from institutions. In other words, institutions confer power on actors; this power can then be used by actors to achieve (material) goals that would otherwise be unachievable. Thus, whilst institutions can influence outcomes, the strategic interaction between actors is not fundamentally changed: actors still seek to maximize their utility (at the expense of other actors).

The following quotation from the IMF (1999, p. 106) illustrates well the different understanding that neoclassical economists have of the role that institutions can play in influencing economic outcomes from that which underpins many of the contentions within the varieties of capitalism paradigm. Institutions are seen, firstly, as providing actors with power that can then be used to impede the efficient functioning of the labour market, and, secondly, as an incentive (or disincentive) structure that plays no real part in conditioning the strategic interaction between actors:

This [evidence suggesting that employment in Europe failed to increase after periods of slow growth or recession coincided with real-wage increases] is consistent with the 'insider-outsider' model of unemployment and real wages, where unions negotiate on behalf of employed individuals (or union members, an even narrower constituency), rather than representing the interest of the wider labour force or the entire economy. The bargaining position is strengthened by job-protection legislation, which reduces the (immediate) threat of job loss, while generous unemployment benefits reduce the pressure on the unemployed to price themselves into employment. ${ }^{14}$

Thus, unions use their power-which is, in part, derived from job-protection legislation as well as 'generous unemployment benefits' - to achieve higher wage deals than companies would otherwise pay at the expense of companies and 'outsiders' (the unemployed or non-unionized workers).

\section{Actors' strategic preferences}

Given the affinities between the varieties of capitalism approach and transaction cost economics discussed above, it might be surprising to learn that, like neoclassical economists, but unlike writers who favour the varieties of capitalism approach, transaction cost economists have been highly critical of state-supported

\footnotetext{
14 The IMF's position on the effects that union composition has on economic outcomes is similar to that of Calmfors and Driffil (1988, pp. 13-61). The 'insider-outsider' problem was originally formulated by Lindbeck and Snower (1988).
} 
institutions such as co-determination. It will be argued here that the main reason for this discrepancy between the varieties of capitalism approach and transaction cost economics is that the two approaches make contrasting assumptions about the formation of actors' strategic preferences.

For transaction cost economists - as well as for neoclassical economists ${ }^{15}$ interests and strategic preferences are exogenous to the institutional framework in which they are set. In short, institutions do not fundamentally alter the strategic preferences of actors. ${ }^{16}$ Therefore, despite the fact that transaction cost economists disagree with neoclassical economists on the role that institutions can play in acting as safeguards for certain kinds of investment (i.e. those that are specific to an asset or relationship and that cannot be used for other purposes), they are in agreement with neoclassical economists that state-supported institutions, such as works councils and co-determination, are inappropriate for workers with general skills. As Williamson (1985, p. 302; see also Pejovich, 1998, p. 192; Furubotn and Richter, 1998, p. 397) has written:

That argument [that co-determination should extend the influence of workers to include general investment issues, planning and output decisions] is clearly mistaken as applied to workers with general purpose skills and knowledge. Such workers can quit and be replaced without productive losses to either worker or firm.

In this view, then, firms will not adjust their strategies to take advantage of the opportunities that are, potentially, created by the institutional setting in which they operate. A corollary of such thinking is that institutions will not influence the strategic preferences of companies: firms will not adapt to the institutional framework, ${ }^{17}$ and, thereby, will not become dependent upon the institutional framework for their production strategies, which, if successful, will, in turn, change their preferences about institutions that they may, initially, have objected to. In short, in neoclassical and transaction cost economics pre-strategic preferences are not fundamentally different to strategic ones.

Such thinking stands in sharp contrast to the arguments within the varieties of capitalism approach; this is perhaps the main difference between the transaction cost approach and the varieties of capitalism approach. Within the latter literature,

\footnotetext{
${ }^{15}$ Important texts on preferences being exogenous for neoclassical economists are Friedman (1962, p. 13), Becker (1976, p. 133), and Stigler and Becker (1977).

${ }^{16}$ Although, within analyses that are based on the assumptions of transaction cost economics, preferences may change over time, they are not seen as being endogenous to the institutional setting in which actors operate (North, 1990, p. 17; Furubotn and Richter, 1998, p. 3).

${ }^{17}$ Cf. North (1990, p. 7) where he contends that 'organizations' are created to take advantage of the opportunities that are determined by 'institutions'.
} 
it is common for the strategic preferences of firms to be treated implicitly as endogenous to the institutional setting; that is, institutions can influence firm preferences. ${ }^{18}$ As Hall and Soskice (2001, p. 15) have written: ${ }^{19}$

firms located within any political economy face a set of coordinating institutions whose character is not fully under their control. These institutions offer firms a particular set of opportunities; and companies can be expected to gravitate toward strategies that take advantage of these opportunities. In short, there are important respects in which strategy follows structure. For this reason, our approach predicts systematic differences in corporate strategy across nations, and differences that parallel the overarching institutional structures of the political economy.

This quotation shows that, within the varieties of capitalism paradigm, firms can be expected to change their strategies to take advantage of the opportunities afforded to them by the institutional setting in which they operate.

Though the quotation does not indicate that Hall and Soskice argue that firms change their preferences, the whole thrust of the varieties of capitalism paradigmwhich seeks to defend economies, such as the German one, that do not adhere closely to the precepts of neoclassical thinking - suggests that an assumption within the varieties of capitalism framework is that institutions can change preferences. This assumption appears to underpin the following quotation. Hall and Soskice (2001, p. 57) have contended that:

firms based in LMEs may be more inclined to move their activities abroad to secure cheaper labour than companies based in CMEs, because the former already coordinate their endeavours using the market structures that less developed nations usually provide, while the latter often pursue corporate strategies that rely on high skills and institutional infrastructure difficult to secure elsewhere.

This quotation suggests, then, that companies in CMEs (even if they initially or 'pre-strategically' objected to certain parts of the institutional infrastructure) will come to look favourably on the institutional infrastructure in which they operate, as they will be cognizant of the fact that it supports their corporate strategies, and they will continue to invest in their home CME even when other investment

\footnotetext{
${ }^{18}$ For an espousal of how institutions can shape preferences see Thelen and Steinmo (1992, pp. 1-32) and Hall (1992, pp. 90-113).

${ }^{19}$ It should be noted that Hall and Soskice, in an effort to avoid accusations of determinism, also go on to note that there will, of course, be variation in corporate strategies in all nations that are not dependent on the institutional framework.
} 
opportunities in low-cost, less-developed countries exist. Thus, institutions, within the varieties of capitalism paradigm, can change the strategic preferences of firms.

\section{The origins of institutions}

Why do Hall and Soskice make this implicit assumption about preference formation? The answer stems, in part at least, from a related assumption about the origins of institutions. Despite the fact that the varieties of capitalism paradigm shares many of its underlying assumptions with transaction cost economics, the varieties of capitalism framework assumes, unlike transaction cost economics, that the institutions that matter are those that are national and that can be taken as given (Hall and Soskice, 2001, p. 15). They contend that an individual firm is, to a large extent, incapable of shaping the institutional setting in which it must operate. This contrasts strongly with the view taken in the transaction cost literature that firms are able to set up whatever institutions they need to support their production strategies. ${ }^{20}$ For instance, Williamson (1985, p. 303) has written that: 'Ordinarily, it can be presumed that workers and firms will recognize the benefits of creating [a] specialized structure of governance to safeguard firm-specific assets.'

Within the varieties of capitalism paradigm, by contrast, this specialized structure of governance to safeguard firm-specific assets is assumed to have been created by the state and by social processes. ${ }^{21}$ This assumption about the origins of institutions is, as noted above, related to the premise in the varieties of capitalism paradigm that the strategic preferences of companies are endogenous to the institutional framework in which firms operate. This can be explained as follows: as Hall and Soskice cannot argue that firms supported the introduction of co-determination — indeed, firms fought against it (Pejovich, 1998, p. 191), as they did against the extension of (some) co-determination rights to small companies in the summer of 2002 - and because they and others, such as Thelen and Wood, seek to argue that companies have come to rely on the national institutional framework to support their production strategies, they have to assume implicitly that strategic

\footnotetext{
${ }^{20}$ Hall and Soskice's approach is, therefore, ultimately, a structuralist one; whereas the transaction cost approach is an actor-centred one.

${ }^{21}$ Some of those who write within the varieties of capitalism framework have argued that firms can establish collective insitutions (see, e.g. Hancké, 2001); however, Hancké notes that when this occurs it is the result of firms acting in concert rather than individually. The key distinction between the varieties of capitalism framework and transaction cost economics is, in this respect, that, within the former, cardinal institutions are the result of some form of collective action, whereas, in the latter, important institutions can be established by individual firms.
} 
preferences can be shaped by the institutional setting in which firms operate. ${ }^{22}$ If the strategies and preferences of firms were not endogenous to the institutional setting, firms would be as opposed to works councils and other aspects of co-determination now as they were when co-determination was introduced. This, in turn, would mean that firms would seek to undermine fundamental parts of the German economic model. Yet Thelen $(2000,2001)$ and Wood (2001) attempt to show that this is not the case. They both, independently and very broadly, contend that, whilst German employers have sometimes been extremely vociferous in their criticisms of aspects of the German economic model, such as collective bargaining and works councils, they have failed to undertake fundamental reforms of the model even when they were presented with the opportunity to do so.

\section{The 'spread' of institutions}

Focusing on the assumptions made within the varieties of capitalism framework on the origins of institutions highlights not only the fact that authors formulate their arguments based on an unstated presupposition about the formation of strategic preferences, but also that some authors assume that national economic institutions are spread uniformly across firms and sectors. For instance, in attempting to argue that employment protection legislation facilitates the provision of firm-specific skills, Estevez-Abe et al. (2001, p. 149-55) have, inter alia, examined macro data on tenure rates in 18 OECD countries. In the case of Germany, they thereby assume that the vast majority of firms adhere to the ideal type within the varieties of capitalism framework. For example, they assume that, more or less, every company in Germany has a works council; however, such an assumption is being increasingly called into question. Streeck (1997), for example, has spoken of 'co-determination free zones' in Germany.

This shortcoming is also apparent in some analyses at the meso level (sectoral data) (though cf. Thelen and Kume, 1999, who, although writing within a broad variety of capitalism perspective, note the declining coverage of collective agreements in the metalworking industries). For instance, Germany's export performance (Soskice, 1999, pp. 112-18) as well as its success in incremental innovation (Hall and Soskice, 2001, pp. 41-4) in certain sectors have been adduced to support

\footnotetext{
22 This view of preference formation is different to that taken in sociological institutionalism in which preferences can also be shaped by institutions, but in which preferences, once formed, become less malleable. For instance, sociological institutionalists might argue that employers who have been socialized in a CME would attempt to pursue production strategies based on cooperative relations with labour, even if they were moved to an LME; writers who favour the varieties of capitalism paradigm would, presumably, argue that such managers would adjust their production strategies to the new institutional setting in which they find themselves.
} 
the contentions made within the varieties of capitalism paradigm; however, these studies, like those that are based on macro data, suffer from an inability to show explicitly that it is the institutions of the German economic model, most notably works councils, that are, in large part, responsible for these outcomes. That fact that works councils and collective agreements can no longer be assumed to be a feature of nearly all companies in Germany leads to doubts about the validity of conclusions that are based on aggregated data (be it at the sectoral or national level) that ignore this uneven spread of institutions. For instance, it could, arguably, be the case that it is those companies that have neither a works council nor a collective agreement that export the most, and that engage in incremental innovation more often than co-determined companies. Unless analyses attempt to link, on the one hand, firm- or plant-level data on the type of collective agreement that companies conclude (collective, company or plant) and information on the presence or absence of a works council to, on the other, firm- or plant-level outcomes (exports, innovation, etc.) the results will be indeterminate.

One thing that might help to explain the research strategies of those, such as Hall and Soskice, who have sought empirical evidence to buttress the arguments within the varieties of capitalism paradigm is that the implicit foil against which they are testing their arguments is neoclassical economics. ${ }^{23}$ As is evident in some of the studies that are critical of the German economic model, neoclassical economists tend, ultimately, to focus on macro-level outcomes (aggregate investment figures, aggregate unemployment data) when assessing the impact of institutions on outcomes. Thus, critics (of aspects) of the German economic model often point to the high levels of German direct investment, low levels of foreign direct investment in Germany (the Standortdebatte), ${ }^{24}$ high levels of unemployment in Germany (Siebert, 1997; Sinn, 2002), and the high number of bankruptcies to show that the 'rational' response of companies in Germany is, respectively, to invest more abroad and less at home, to hire capital and not labour, or to go bust. ${ }^{25}$ Given the levels of criticisms of the German economic model that are broadly neoclassical in their orientation and that are often present in the mainstream media, it is, perhaps, not surprising that some, such as Hall and Soskice, who have sought to defend the German economic model have tended to make the same assumptions as those criticizing it; namely, that the majority of firms in Germany adhere to the ideal type presented in the varieties of capitalism framework.

\footnotetext{
${ }^{23}$ This point is illustrated by the fact that Hall and Soskice distinguish between 'co-ordinated market economies', such as Germany, and 'liberal market economies', such as the USA and the UK, which adhere most closely to the ideal type premised in many neoclassical analyses.

${ }^{24}$ For an attempt to assess German direct investment in a more holistic light, see Allen (2002a).

${ }^{25}$ See Funk (2002) for a discussion of some of these issues.
} 


\section{Conclusions}

This article has sought to clarify some of the unstated assumptions that underpin the varieties of capitalism theoretical framework by comparing it with two competing approaches that come to radically different assessments about the benefits of state-supported institutions, such as co-determination, despite the fact that the varieties of capitalism approach draws extensively on some of the arguments that were first proposed within one of those alternative approaches. By comparing the varieties of capitalism paradigm with transaction cost economics, it has been possible to highlight assumptions made in the former, firstly, about the strategic preferences of firms being endogenous to their institutional environment, and, secondly, about the, more or less, uniform spread of important institutions.

Yet, by making this latter assumption, Hall and Soskice ultimately run this risk of obviating one of their main aims; that is, to put the firm at the centre of their analyses. Paradoxically, then, despite Hall and Soskice's claim (2001, p. 6, italics removed) that the 'varieties of capitalism approach to the political economy is actor-centred', within the approach the differences between firms are irrelevant: all firms are assumed to adhere to the ideal type of firm in a CME or an LME, and can adapt to become, respectively, incremental or radical innovators. It is the structure of the national economy, not the differences between firms, that largely determines the actions of firms. Yet, as noted above, firms do differ. Therefore, despite the important differences between the varieties of capitalism, the differences between the varieties of firms-in terms of their structures and goals—-might be of greater importance in explaining the actions of companies.

\section{References}

Allen, M. (2002a) 'German Direct Investment: A Substitute for Domestic Investment?', German Politics, 11, 125-46.

Allen, M. (2002b) 'Works Councils and Collective Agreements: Necessary Evils?' In Funk, L. and Green, S. (eds) New Challenges to Active Labour Market Policy, Berlin, VWF, pp. 54-74.

Arrow, K. (1999) 'Foreword'. In Carroll, G. and Teece, D. (eds) Firms, Markets and Hierarchies: The Transaction Cost Perspective, Oxford, Oxford University Press, pp. vi-x.

Becker, G. (1976) The Economic Approach to Human Behaviour, Chicago, University of Chicago Press.

Calmfors, L. and Driffil, J. (1988) 'Bargaining Structure, Corporatism and Macroeconomic Performance', Economic Policy, 6, 13-61.

Culpepper, P. D. (2003) Creating Cooperation: How States Develop Human Capital in Europe, Ithaca and London, Cornell University Press.

Estevez-Abe, M., Iversen, T. and Soskice, D. (2001) 'Social Protection and the Formation of Skills: A Reinterpretation of the Welfare State'. In Hall, P. A. and Soskice, D. (eds) Varieties 
of Capitalism: The Institutional Foundations of Comparative Advantage, Oxford, Oxford University Press, pp. 145-83.

Funk, L. (2002) 'The "Storm before the Calm" Thesis Re-examined'. In Leonhard, J. and Funk, L. (eds) Ten years of German Unification: Transfer, Transformation, Incorporation?, Birmingham, Birmingham University Press, pp. 183-210.

Hall, P.A. (1992) 'The Movement from Keynesianism to Monetarism: Institutional Analysis and British Economic Policy in the 1970s'. In Steinmo, S., Thelen, K. and Longstreth, F. (eds) Structuring Politics: Historical Institutionalism in Comparative Politics, Cambridge, Cambridge University Press, pp. 90-113.

Hall, P. A. (2001) 'The Evolution of Economic Policy-Making in the European Union'. In Menon, A. and Wright, V. (eds) From Nation State to Europe? Essays in Honour of Jack Hayward, Oxford, Oxford University Press, pp. 214-45.

Hall, P. A. and Soskice, D. (2001) 'Introduction'. In Hall, P. A. and Soskice, D. (eds) Varieties of Capitalism: The Institutional Foundations of Comparative Advantage, Oxford, Oxford University Press, pp. 1-68.

Hanké, B. (2001) 'Revisiting the French Model: Coordination and Restructuring in French Industry'. In Hall, P. A. and Soskice, D. (eds) Varieties of Capitalism: The Institutional Foundations of Comparative Advantage, Oxford, Oxford University Press, pp. 307-36.

IMF (1999) World Economic Outlook May 1999: A Survey by the Staff of the International Monetary Fund, Washington DC, IMF Publication Services.

Kasper, W. and Streit, M. E. (1998) Institutional Economics Social Order and Public Policy, Cheltenham, UK and Northampton, USA, Edward Elgar.

Lindbeck, A. and Snower, D. J. (1988) The Insider-Outsider Theory of Employment and Unemployment, Cambridge, MA, MIT Press.

Milgrom, P. and Roberts, J. (1992) Economics, Organization and Management, New Jersey, Prentice Hall.

North, D. C. (1990) Institutions, Institutional Change and Economic Performance, Cambridge, Cambridge University Press.

North, D.C. (1997) 'The Contribution of the New Institutional Economics to an Understanding of the Transition Problem, WIDER Annual Lectures 1, at http://www.wider.unu.edu/publications/annual-lectures/annua-lecture-1997.pdf

Ostrom, E. (1990) Governing the Commons: The Evolution of Institutions for Collective Action, New York, Cambridge University Press.

Pejovich, S. (1998) Economic Analysis of Institutions and Systems, revised second edition, Dordrecht, Kluwer.

Scott, K. (1994) 'Bounded Rationality and Social Norms: Concluding Comment', Journal of Institutional and Theoretical Economics, 150,315-19.

Siebert, H. (1997) 'Labour Market Rigidities: At the Root of Unemployment in Europe', Journal of Economic Perspectives, 11,37-54.

Simon, H. A. (1961 first published 1947) Administrative Behaviour, New York, Macmillan. 
Sinn, H.-W. (2002) 'Germany in the World Economy-Hope Springs Eternal', CESifo Forum, 3, No. 2.

Soskice, D. (1999) 'Divergent Production Regimes: Coordinated and Uncoordinated Market Economies in the 1980s and 1990s'. In Kitschelt, H., Lange, P., Marks, G. and Stephens, J. D. (eds) Continuity and Change in Contemporary Capitalism, Cambridge, Cambridge University Press, pp. 101-34.

Stigler, G. J. and Becker, G. S. (1977) 'De gustibus non est disputandum', American Economic Review, 67, 76-90.

Streeck, W. (1997) 'Beneficial Constraints: On the Economic Limits of Rational Voluntarism'. In Hollingsworth, R. J. and Boyer, R. (eds) Contemporary Capitalism: The Embeddedness of Institutions, Cambridge, Cambridge University Press, pp. 197-219.

Thelen, K. (2000) 'Why German Employers Cannot Bring Themselves to Abandon the German Model'. In Iversen, T., Pontusson, J. and Soskice, D. (eds), Unions, Employers and Central Banks, New York, Cambridge University Press.

Thelen, K. (2001) 'Varieties of Labour Politics in the Developed Democracies'. In Hall, P. A. and Soskice, D. (eds) Varieties of Capitalism: The Institutional Foundations of Comparative Advantage, Oxford, Oxford University Press, pp. 71-103.

Thelen, K. and Kume, I. (1999) 'The Effects of Globalization on Labor Revisited: Lessons from Germany and Japan', Politics and Society, 27, 477-505.

Thelen, K. and Steinmo, S. (1992) 'Historical Institutionalism in Comparative Politics'. In Steinmo, S., Thelen, K. and Longstreth, F. (eds) Structuring Politics: Historical Institutionalism in Comparative Politics, Cambridge, Cambridge University Press, pp. $1-32$.

Williamson, O. E. (1985) The Economic Institutions of Capitalism, New York, The Free Press.

Williamson, O. E. (2000) 'The New Institutional Economics: Taking Stock, Looking Ahead', Journal of Economic Literature, 38, 595-613.

Wood, S. (2001) 'Business, Government, and Patterns of Labour Market Policy in Britain and the Federal Republic of Germany'. In Hall, P. A. and Soskice, D. (eds) Varieties of Capitalism: The Institutional Foundations of Comparative Advantage, Oxford, Oxford University Press, pp. 247-74. 